\title{
Metaphoric Perception of Gifted Students about Physical Education Course and Physical Education Teachers
}

\author{
Aynur Yilmaz ${ }^{1}$, Oguz Kaan Esenturk ${ }^{2}$, Gonul Tekkursun Demir ${ }^{2} \&$ Ekrem Levent Ilhan ${ }^{2}$ \\ ${ }^{1}$ Faculty of Sport Sciences, Kırıkkale University, Kırıkkale, Turkey \\ ${ }^{2}$ Faculty of Sport Sciences, Gazi University, Ankara, Turkey \\ Correspondence: Aynur Yilmaz, Department of Physical Education and Sport, Faculty of Sport Sciences, \\ Kırıkkale University, Kırıkkale, Turkey. E-mail: aynuryilmaz@kku.edu.tr
}

Received: December 19, 2016

Accepted: January 20, 2017 Online Published: February 13, 2017

doi:10.5539/jel.v6n2p220

URL: http://doi.org/10.5539/jel.v6n2p220

\begin{abstract}
It is to determine the perception of the gifted students who participate to "Science and Art Center" about "Physical Education Course" and "Physical Education Teachers" via metaphors. The working group of the research consists of 48 students who participate Science and Art Center in 2014-2015 school years. Among the purposive sampling methods, criterion sampling method is used in choosing the working group. In the research, among the qualitative research approaches, phenomenological design is used. The data is gathered by semi-structured metaphor form and gathered data have been subjected to content analysis. It was seen that, toward the physical education, they described it in a way that includes positive qualifications as a good lecture, a mean of freedom, a source of life, an educating activity, a competition area and a natural event. It was determined that generally the students' perception towards physical education teachers are positive and they are described as a mentor, compassionate, fun, capable, knowing, hard-working and strong. It can be said that the students see the physical education more as a mean to have fun, to have great time and to move freely. The physical education teacher is also described as a mentor, compassionate and fun person.
\end{abstract}

Keywords: gifted students, metaphor, physical education course, pysical education teacher

\section{Introduction}

The future of nations depends on the physical and spiritual maturity of the youth who are growing up or have already grew up. What is expected from the education is to help the individuals' development at the highest level by revealing their skills and potentials (Erkal et al., 1998). Every stages of education period have importance on these expectations. According to Güven (2007), the main aim of the education period is to help the individuals accommodate healthfully and productively to society. Education attaches also importance to cognitive, physical, psychomotor, emotional and social dimensions for the development of individual as a whole and enhancing the mental characteristics (Demirhan, 2006).

To keep up with the age changing fast nowadays, it is needed to raise agreeable, creative, innovative, self-confident individuals who have freewill and ability of self-expression. Physical education course considered as an irreplaceable factor of education has an important on raising individuals with these characteristics. The fact that this course having an important share on development of individual contribute to upbringing of individuals is possible only with a qualified education (Canakay, 2006). The quality of teacher who is an executive of education is also important on reaching the qualified education. Because no matter which course it is, teachers determining the environment of education play important roles such as endearing the courses to students, providing them to learn and making them feel the importance of courses (Harrison \& Blakemore, 1992; Sahin, 2013). Potential perception towards course has a great effect on success in course (Sahin, 2013). Students can have positive and negative thoughts on physical education courses as much as on any course. The fact that students have positive thoughts on physical education courses can make it easier to reach the general and specific purposes of course by providing physical activities to be performed productively or can support the participations of students willingly to various physical activities in future (Silverman \& Scrabis, 2004). This indicates that in the period of education, the fact that teacher's ability of performing the course productively and satisfying the expectations of students on potential attitudes and behaviors towards course is described as important criteria. 
Kirk and Gallagher (1989) stated that in the education of gifted students defined as children displaying high performance capacity in the fields such as creative, art and leadership or requiring activities in the exclusive academic fields, which they can't obtain in school to develop completely these capacities (cited by: Ocak \& Beskardes Günay, 2009), it is an undeniable truth that physical education course is important, at least, as much as other courses. To keep up with the age changing fast nowadays, it is needed to raise agreeable, creative, innovative, self-confident individuals who have freewill and ability of self-expression (Canakay, 2006). Physical education which has an important role on development of individual needs also qualified physical education courses to raise qualified individuals. Teacher has an effect on perspectives of students towards course. Teachers who are responsible for regulating the education environment students come across or who are a role model for students are important in terms of perception way of students (Cerit, 2008). Students having positive attitudes towards physical education teachers like courses, their interests towards course increase and get pleasure from course.

Metaphors are mental constructs (Lakoff \& Johnson, 1980) that lie beneath the surface of a person's awareness and serve as a cognitive device for analogical framing and the defining of experience in order to achieve meaning about life (Massengill Shaw \& Mahlios, 2008). According to Billot and King (2015), usually a metaphor communicates an idea or feeling about something; however, it is sometimes used when something is difficult to express. In effect, metaphors explain, clarify, describe, express, evaluate and entertain. Low, Deignan, Cameron and Todd (2010) take this definition further, to assert that metaphor is ubiquitous and crucial in expressing abstract thought. Sackman (1989), metaphor, defined as a language form applied on a different content to express a specific similarity of a term or concept (cited by: Yıldırım \& Simsek, 2011), is evaluated as a powerful mental tool that in recent years individual can set to work on understanding and explaining a complicated, theoretic and abstract phenomenon at high level (Yob, 2003). According to Lakoff and Johnson (2010), this concept is "It is a process of understanding and experiencing in the perspective of another thing, expressing a thought material with a form of human comprehension". The aim of metaphor is to understand. "Since many concepts that are important for us aren't clearly expressed either abstractly or on our experiences (emotion, thoughts, time etc.), we need to comprehend the unknowns through other concepts we can understand with clearer terms" (Lakoff \& Johnson, 1980).

Metaphor is not only a statement figure, but also a thought figure. There are people supporting that metaphoric thinking process consists of two categories. One of these categories is "subject", the other is "tool". Subject is a concept, situation or phenomenon explained or asked to be explained. Tool is a term or terms used metaphorically (Balc1, 1999). In this respect, metaphor is a perfect technical to learn unknown things, and a tool, validity of which is proven in terms of remembering and keeping in mind the learnt knowledge. With metaphor, students connect new knowledge by attaching to schema existing already in mind to old knowledge. In this way, metaphors increase the quality of learning process by creating vivacious images and making strong contacts between concepts learnt newly and past learning and personal experiences of students (Arslan \& Bayrakc1, 2006).

In literature, there are researches related to metaphor conducted on the gifted students. In these researches (Ocak \& Beskardes Günay, 2009; Eraslan Capan, 2010; Mertol, Doğdu, \& Yılar, 2013; Özsoy, 2014; Thomas \& Beauchamp, 2011), metaphors related to different concepts studied with teacher candidates, teachers and family were researched. Among these studies, study that measures perception towards physical education course and physical education teacher wasn't encountered. It is thought that determining the perceptions towards physical education course and physical education teacher considered as an executive of this course that are considered that they have a great role in terms of development of gifted students, can be beneficial in terms of understanding what kind of expectations these students have from the course. Answers for following questions were searched to obtain the perceptions of gifted students towards the concepts of physical education course and physical education teacher through metaphors.

- What are the metaphors that gifted students produced regarding physical education course?

- In which cognitive categories can the metaphors gathered which are obtained towards physical education course?

- What are the metaphors that gifted students produced regarding physical education teacher?

- In which cognitive categories can the metaphors gathered which are obtained towards physical education teacher? 


\section{Method}

In present research conducted to determine the perceptions of gifted students towards the concepts of physical education course and physical education teacher; for the purpose of collecting detailed and in-depth data, learning directly the individual perception, experiences and perspectives of participants, understanding and expressing the current situation, out of the qualitative approaches (Büyüköztürk et al., 2009; Denzin \& Lincoln, 2005; Yin, 2003) phenomenology design trying to determine the experiences, perceptions and meanings that individuals assign to these, was used (Casey, 2009; Yıldırım \& Simsek, 2011). Phenomenology seeking an answer for the question of (What is the truth?) and which is a design approach of which is formed by individual experiences (Bas \& Akturan, 2013), deals with the subjects of how human perceive a phenomenon, how they describe it, remember it, evaluate it and what kind of language they use to transfer it to other humans (Patton, 2001). Interpretive phenomenon defined as interpreting of "texts" (hermeneutics) related to life and directing the research to experience out of these design varieties (Creswell, 2013) was used.

\subsection{Research Group}

To this research conducted in spring semester in 2013-2014 academic years, $5^{\text {th }}, 6^{\text {th }}$ and $7^{\text {th }}$ grade students from the city of Trabzon and Kurikkale who participate in Art and Science Centers and totally 48 students were consisted. Since starting point of phenomenology constituting the research design is individual experiences, people who experienced or are still experiencing these (Bas \& Akturan, 2013) were included in research. For this purpose, purposeful group sample enabling situations to be studied deeply, which is considered that they have rich knowledge in terms of collecting detailed data about subject, being high of data quality and revealing the perception towards physical education course and physical education teacher having an important effect on development of student (Patton, 2001) was used. It was paid attention that within this knowledge, participants should have experience towards the concepts of physical education course and physical education teacher. 26 female, 22 male and totally 48 gifted students are composed of the research. 10 of participants $(20.8 \%)$ are $5^{\text {th }}$ grade, $23(47.9 \%)$ are $6^{\text {th }}$ grade and $15(31.2 \%)$ are $7^{\text {th }}$ grade students.

\subsection{Data Collection}

Metaphor form was used as a data collection tool in research. Metaphors are used for the purpose of decreasing the qualitative research's complication in patters that are clearly structured (Schmitt, 2005). To determine the participant metaphors, two approaches are generally used. First one is conducted with general use of metaphors (named often as "nature metaphors"). These are inferences from expression examples formed "naturally" of personal stories, meetings, interviews and readings (Armstrong, 2008). Second metaphor approach of Jin and Cortazzi (2011), participants use on purpose specific metaphors like "learning is parallel to..." (cited by: Wan, 2014). Results are certain metaphors and generally they are formed in the way of " $x$ is parallel to $y$ ". When compared studying with specific metaphors in expression examples with coding in using nature metaphor, it shows tendency of being clearer/truer. Since researchers create a form of metaphor style and give a contextual subject, participants are asked only for tool terms. What researchers should do is to control whether or not the tools are metaphor and whether any of them contain use having the characteristic of metaphor or not (Wan, 2014).

Before preparing the data collection tool, some studies related to subject (Saban, 2008; Cerit, 2008; Aydin \& Ünald1, 2010; Gömleksiz, Kan, \& Öner, 2012; Soysal \& Afacan, 2012; Ungar, 2016; Yalcın \& Erginer, 2012; Tortop, 2013; Özbas \& Aktekin, 2013; Demirtas \& Coban, 2014; Özsoy, 2014; Emerson \& Mansvelt, 2014; Wan, 2014; Y1lmaz \& Güven, 2015; Cansever \& Aslan, 2016) were researched to figure out what kind of data collection tool individual use on determining the metaphoric perceptions towards any concepts, and it was determined that generally as a data collection tool "specific metaphor" approach including open ended question form was used. It was decided to use the "food metaphor" approach for the purpose of determining the gifted students' perceptions towards the concepts of "physical education course" and "physical education teacher". Data collection tool consists of two categories. Whilst the first category consists of the questions containing demographic characteristics such as age, sex, level of class, second category consists of the sentences such as "physical education course is like/parallel to...; because..." and "Physical education teacher is like/paralell to...; because..."

In metaphor studies, the concept of "like" is asked generally to evoke in a clearer way the connection between the subject of metaphor and resource of metaphor, and the concept of "because" is asked to present a reason (or a reasonable baseline) for presented metaphor (Saban, 2008). This is because, for approval of phenomenon as a metaphor; it should have subject, resource and characteristics (reason) considered to be attributed from resource to subject (Forceville, 2002). For instance, "academic writing is like being in a contest, I am behind the group 
that doesn't know where the front is" (Armstrong, 2008). Hereby, the subject of cognitive metaphor is contest. The resource of metaphor is the way of expressing the contest. For the purpose of collecting quality information from participants, metaphor concept was explained to students before starting to collect data and preliminary was done by presenting examples from conducted studies and thus it was tried to obtain valid data. Before this application, the importance of concentrating enough on concept to obtain healthful and meaningful metaphor was emphasized to students. Forms, prepared to determine the gifted students' thoughts and emotions related to concepts of physical education course and physical education teacher, were fulfilled within 20 minutes by students.

\subsection{Data Analysis}

Data analysis in phenomenology researches aims to reveal the experiences and the things told. Therefore, in conducted content analysis, there is an effort to reveal the themes that can define the conceptualization of data and phenomenon. Findings obtained pursuant to revealed themes and patterns are explained and interpreted (Bauer, 2003; Fraenkel \& Wallen, 2000). Before starting to data analysis, the papers of participants were numbered from K1 to K48. Obtained data were evaluated in content analysis. Content analysis requires in-depth analysis of collected data and by this means, it is provided to reveal the themes that were indeterminate previously. Thus, data resembling to each other are gathered in pursuant to specific concepts and themes, and they are arranged, interpreted to be understood by reader (Yıldırım \& Simsek, 2011). The process of interpreting and analyzing the data obtained in present research was done by considering the stages used by Saban (2008). These stages are respectively:

Elimination stage: in analysis of word/metaphor, by concentrating deeply on key word, concept, metaphor to clarify a subject or idioms, researchers deal with determination of these and what they mean (Ekiz, 2009). For this purpose, by looking over the metaphors produced for the concepts of physical education course and physical education teacher by gifted students, it was analyzed in terms of resource of metaphor, subject of metaphor and the relation between subject and resource of metaphor. Whether the metaphors towards these two concepts are meaningful or not were researched and 6 papers considered as meaningless weren't evaluated (n: 48). Numbering of papers: After taking the 6 papers out, produced by participants, containing meaningless or lacking metaphor images; during analysis, every remained papers were numbered from K1 to K48 to unclutter and also to include the participant quotations in presenting data. Compiling and category stage: By conducting content analysis on obtained data, coding was done. Primarily, obtained metaphors were lined up alphabetically and analyzed according to resource of metaphor, subject of metaphor and the relation between subject and resource of metaphor; handled meaningfully under a theme. Providing the validity and reliability stage: Yildirım and Simsek (2011) define the validity and reliability in qualitative research as "reporting detailed the collected data and explaining of researchers how they reach a result, are included in criterion of svalidity in a qualitative research". For this purpose, information related to how the data were collected and analyzed in the process of research were explained step by step. In addition to this, student statements related to metaphors included in categories created with reference to produced metaphors were included. For the validity of categories obtained in research, whether or not there is a reasonable relation between metaphors produced by participants and resource of metaphors in terms of content and meaning was confirmed by academic member who is specialist in his/her field. For reliability of data analysis, data obtained by researcher and domain expert were separately lined up, obtained data were compared, and points among which there is agreement and difference of opinion were figured out. When the percentage of agreement in calculation of the reliability is $70 \%$, it is accepted that reliability percentage is achieved (Yıldırım \& Simsek, 2011). For this calculation, the formula of Miles and Huberman (1994) was used (Reliability=agreement/(agreement+difference of opinion)x100). As a result, the reliability coefficient of research was found as $94 \%$. For reliability of data analysis, it was appeared that as a result of expert opinion "ice cream and an excited human" metaphors were handled under different categories. Ice cream metaphor was handled under the category of "physical education as a nice and entertaining course" and an excited human metaphor was handled under the category of "physical education as a life resource". "A complicated deadlock and dream" metaphors towards the concept of physical education teacher were handled under different categories. These differences were removed with reconciliation among experts. Also, in creating the model of cognitive structures related to concepts of the participants was used the NVivo 10 packet program. 


\section{Results}

In this section, students' metaphors towards the concepts of "physical education course" and physical education teacher were researched under some cognitive categories according to common trait and numerical information belonging to categories were included. Later examples from metaphors constituting the categories were presented and traits of some categories were supported by citing from metaphors of students.

\subsection{The Analysis of Metaphors Produced by Gifted Students for the Concept of Physical Education Course}

Answering research's this sub-purpose, concepts that are similar in terms of content were handled under same category by evaluating the data obtained from gifted students. In Table 1, metaphor constituting categories determined as a result of analysis of data obtained from students and resource that explain metaphor were presented.

Table 1. Gifted attitudents' metaphors produced for the concept of physical education course

\begin{tabular}{|c|c|c|c|}
\hline Categories & Subject of metaphor & Frequency & Resource of metaphor \\
\hline \multirow{4}{*}{$\begin{array}{l}\text { Nice and entertaining } \\
\text { course }\end{array}$} & \multirow{4}{*}{$\begin{array}{l}\text { Entertaining sport (1) Game } \\
\text { (8), Drama (1) Ferris wheel } \\
\text { (1), Adventure (1), Playing } \\
\text { sports (6), Drug (1), } \\
\text { Entertain (2), Game and } \\
\text { entertain (1) }\end{array}$} & \multirow{4}{*}{22} & $\begin{array}{l}\text { "...is like adventure, because in class everything is like } \\
\text { dream. Everybody is in unity." }(\mathrm{K} 42)\end{array}$ \\
\hline & & & $\begin{array}{l}\text { "...is like drug, because it relieves our distress and trouble } \\
\text { and enables us to spend nice time."(K29) }\end{array}$ \\
\hline & & & $\begin{array}{l}\text { “...is like ferris wheel, because we always move and } \\
\text { entertain."(K25) }\end{array}$ \\
\hline & & & $\begin{array}{l}\text { "...is like a drama, because even though it is very tiring, it } \\
\text { learns us a lot. But the aim of both is learning and } \\
\text { entertaining."(K13) }\end{array}$ \\
\hline \multirow{3}{*}{ Tool of strict discipline } & \multirow{3}{*}{$\begin{array}{l}\text { Military service (1), Jail (1), } \\
\text { Ice cream (1), Nightmare } \\
\text { (1) }\end{array}$} & \multirow{3}{*}{4} & $\begin{array}{l}\text { "...is parallel to jail, because it pushes us to } \\
\text { loneliness." }(\mathrm{K} 46)\end{array}$ \\
\hline & & & $\begin{array}{l}\text { "... is like an ice cream, at start it is entertaining, delicious, if } \\
\text { it isn't paid attention and consumed a lot, you will get } \\
\text { ill."(K41) }\end{array}$ \\
\hline & & & $\begin{array}{l}\text { "... is like military service, because it is full of statements } \\
\text { like turn right, turn left, let's play a game."(K11) }\end{array}$ \\
\hline \multirow{3}{*}{$\begin{array}{l}\text { Educative and instructive } \\
\text { activity }\end{array}$} & \multirow{3}{*}{$\begin{array}{l}\text { Wood (1), Vase (1), Paste } \\
\text { (1) }\end{array}$} & & $\begin{array}{l}\text { "...is like a wood, because human can assign a meaning to } \\
\text { them and sculpt them."(K38) }\end{array}$ \\
\hline & & 3 & $\begin{array}{l}\text { "...is like a vase, because it can garnish the course with nice } \\
\text { activities, helps our physical development."(K35) }\end{array}$ \\
\hline & & & $\begin{array}{l}\text { "...is like a paste, because it provides formalizing with } \\
\text { actions made in class." }(\mathrm{K} 10)\end{array}$ \\
\hline \multirow[b]{2}{*}{ Life resource } & \multirow[b]{2}{*}{ Ant (1), Life (1) } & \multirow[b]{2}{*}{2} & “... is like an ant, because it asks for much energy."(K39) \\
\hline & & & “...is like a life, because our life.”(K16) \\
\hline \multirow{3}{*}{ Freedom tool } & \multirow{3}{*}{$\begin{array}{l}\text { Pause/Break (2) Relief (2), } \\
\text { Dream (1) Game and Bed } \\
\text { (1) Freedom (2), Holiday } \\
\text { (1) No Teacher in Class (1), } \\
\text { Energy Consuming (1) }\end{array}$} & \multirow{3}{*}{11} & $\begin{array}{l}\text { "... is like a dream, because in dream human feels like free. I } \\
\text { feel like free in physical education course."(K14) }\end{array}$ \\
\hline & & & $\begin{array}{l}\text { "...is like relief, because we are warming up, entertaining } \\
\text { and getting rid of the stress."(K36) }\end{array}$ \\
\hline & & & $\begin{array}{l}\text { "...is like a game and bed because physical education is } \\
\text { very comfortable, very entertaining. It refreshes.(K5) }\end{array}$ \\
\hline Competition area & $\begin{array}{l}\text { Match (1), Game and Sport } \\
\text { (1), An Excited Human (1) }\end{array}$ & 3 & $\begin{array}{l}\text { "...is like an excited person, because everyone wants to win } \\
\text { the contest in force" } \mathrm{K} 1 \text { ) }\end{array}$ \\
\hline \multirow[t]{3}{*}{ Natural event } & \multirow{2}{*}{$\begin{array}{l}\text { Wind (1), Season (1), } \\
\text { Rainbow (1) }\end{array}$} & \multirow{2}{*}{3} & $\begin{array}{l}\text { “...is like seasons because you sweat, feel cold, get sad, } \\
\text { rejoice."(K34) }\end{array}$ \\
\hline & & & $\begin{array}{l}\text { "... is like a rainbow, because it indicates your beauties when } \\
\text { you enter and give you peace." (K45) }\end{array}$ \\
\hline & Metaphor $=32$ & 48 & \\
\hline
\end{tabular}


In Table 1, metaphors produced by gifted students towards physical education course were handled under specific categories by considering the resources. On creating these categories, generally the metaphor studies towards how the course is perceived (Aydın, 2010; Soysal \& Afacan, 2012; Gömleksiz, Kan, \& Öner, 2012) were benefited. It is appeared that metaphors produced by gifted students towards the physical education course were gathered under 7 categories. It is appeared that 6 of them contain positive meaning, whereas 1 of them contains negative meaning. The category having the highest frequency among the categories containing positive meaning is "Nice and entertaining course $(\mathrm{f}=22)$ ". Under this category, metaphors such as "adventure", "entertaining sport", "game", "drama", "ferris wheel" and "game and entertaining" are included. The fact that students describing the physical education course as "drama" use the drama metaphor having an instructive content can be interpreted as it reveals the course's aspect of instructive. For instance, "physical education is like a drama, because even though it is very tiring, it learns us a lot. But the aim of both is learning and entertaining" (K13).

It can be said that participants creating metaphor belonging to category of "Nice and entertaining course", consider that physical education course as a course that has an important influence on personal, social, emotional development. Because it is appeared that produced metaphors are intensively the metaphors such as game, entertaining, sport, drug; and they draw an analogy providing them to relieve by isolating the individual from the situation she/he is in and enable them to experiences nice and entertaining moments. It can be said that the fact that other courses limit the students, contain strict rules and bring cognitive tiredness cause the students to perceive the physical education course, which provides students physical, psychological and emotional comfort, as a drug. The most important reason for this can be interpreted as whilst the other courses are lectured in particular class environment, physical education course are generally lectured outdoors and have a content that presents the students freedom of action.

The category having the second highest frequency is "freedom tool $(\mathrm{f}=11)$ ". In this category, metaphors such as "pause-break, relief, dream, holiday, freedom" were used. For instance; "is like a dream, because in dream human feels like free. I feel like free in physical education course." (K14). The other category stressing the educative and instructive effect of physical education course is "an educative and instructive course $f(3)$ ". Metaphors in this category contain the concepts that is shaped, sculpted and developed. According to $\mathrm{K}(38)$; "Physical education course is like a wood, because human can assign a meaning to them and sculpt them..." (K38). It is seen that every students have different expectations from physical education course and assign meanings to them.

Students explaining the physical education course with metaphors such as life and ant make statements for these. When considered the ant known with its industriousness as moving and energetic, it can be thought that its relation with physical education course is meaningful. According to K39, physical education is "...is like an ant, because it asks for much energy". Similar relation is seen in the interpretation of K16 that associate the physical education with life.

Generally it can be said that metaphors having positive content towards physical education course were used. it can be said that the created categories contain positive content in terms of considering the physical education course as nice and entertaining, instructive and educative, life resource, freedom tool, competition area and natural event. In spite of this, one category characterized the physical education course as a strict discipline tool was obtained. This category includes the metaphors containing psychologically negative situations on humans. When considered the jail and military service as activities requiring a number of discipline rules that restrict the freedom of human, it was seen that order exercises used to maintain the order in physical education course have the same functions. When considered especially the development characteristics of research group on which research applied in terms of children, it was appeared that in present research, students express the ice cream, which is a food that every children love it, in different meanings. According to K41 physical education "is like an ice cream". "At start it is entertaining, delicious, if it isn't paid attention and consumed a lot, you will get ill." This expression can be associated with the fact that physical education course is lectured within discipline and rule. It is shown cognitive constructs related to physical education course of gifted students in Figure 1. 


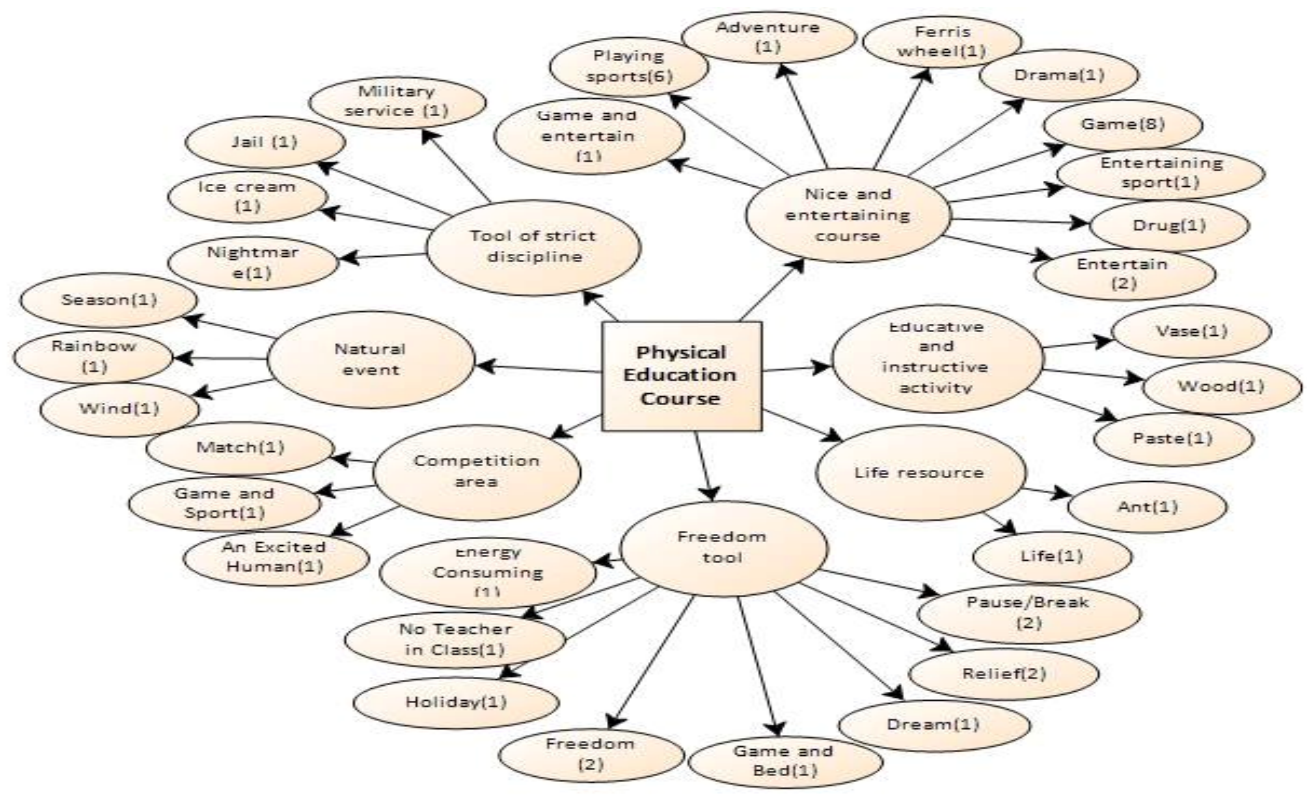

Figure 1. Cognitive constructs related to physical education course of gifted students

\subsection{The Analysis of Metaphors Produced by Gifted Students for the Concept of Physical Education Teacher}

Metaphor frequencies and percentages expressing the thoughts and emotions of gifted students towards physical education teacher are included in in Table 2 in below.

Table 2. Categories related to the concept of physical education teacher

\begin{tabular}{|c|c|c|c|}
\hline Categories & Metaphor subject & Frequency & Metaphor resource \\
\hline Mentor and leader & $\begin{array}{l}\text { Head of game (1), Coach } \\
\text { (2), Pilot (1), Freedom tool } \\
\text { (1), Psychologist (1), } \\
\text { Guide (1), Referee (1) }\end{array}$ & 8 & $\begin{array}{l}\text { “...is like a person that emancipates them, because s/he guides } \\
\qquad \text { us." (K20, } 5^{\text {th }} \text { grade). } \\
\text { “...is like a coach, because in games s/he directs us, show what } \\
\text { we should do in all steps." (K27, } 7^{\text {th }} \text { grade). }\end{array}$ \\
\hline $\begin{array}{l}\text { Possessor of love and } \\
\text { compassion }\end{array}$ & $\begin{array}{l}\text { Guardian angel (2), an } \\
\text { sincere human (1), Flower } \\
\text { (1), Teacher of pre-school } \\
\text { (1), Friend-confidant (2) }\end{array}$ & 7 & $\begin{array}{l}\text { "...is like an angel, because whenever we need help, s/he is } \\
\text { there." (K17, } 5^{\text {th }} \text { grade). } \\
\text { "....is like a flower, because s/he is very soft and beautiful. s/he } \\
\text { presents us beauties even in difficult situations."(K42, } 6^{\text {th }} \text { grade). }\end{array}$ \\
\hline $\begin{array}{l}\text { Provider of control and } \\
\text { discipline }\end{array}$ & $\begin{array}{l}\text { Property (1), Commander } \\
\text { (1), Security staff (2), } \\
\text { Guardian (1), Referee (1) }\end{array}$ & 6 & $\begin{array}{l}\text { “...is parallel with property we use while playing sports, because } \\
\mathrm{s} / \text { he inspects and saves everything." (K22, } 5^{\text {th }} \text { grade). } \\
\text { “...is parallel to commander, because s/he controls the } \\
\text { movement we do and disciplines us." }\left(\mathrm{K} 41,6^{\text {th }} \text { grade). }\right.\end{array}$ \\
\hline An entertaining human & $\begin{array}{l}\text { Film star (1), } \\
\text { Air (1), Ten years old } \\
\text { Child (1), Clown (1), } \\
\text { Comedian (1) }\end{array}$ & 5 & $\begin{array}{l}\text { “...is like an entertaining film star, because when playing a } \\
\text { game, joins in our team and enables us to entertain." (K11, } 5^{\text {th }} \\
\text { grade). } \\
\text { “...is like a clown, because clowns are entertaining." (K14, } 6^{\text {th }} \\
\text { grade). }\end{array}$ \\
\hline An nervous human & $\begin{array}{l}\text { A Scary monster (1), A } \\
\text { Bundle of nerves (1), Hard } \\
\text { Rhock (1), Nightmare (1), } \\
\text { Murderer (1) }\end{array}$ & 5 & $\begin{array}{l}. \ldots \text { is like a murderer, because } \mathrm{s} / \mathrm{he} \text { is angry.”(K28, } 5^{\text {th }} \text { grade). } \\
\text { “....is like a hard rock, because the whole physical education } \\
\text { teachers i know are hard and scary.”( } \mathrm{K} 36,6^{\text {th }} \text { grade). }\end{array}$ \\
\hline Provider to development & $\begin{array}{l}\text { Doctor (1), Mother (1), } \\
\text { Sculptor (1), Sport teacher }\end{array}$ & & "...is like a sculptor, because s/he shapes our movements, lives." \\
\hline
\end{tabular}




\section{(1), Civil engineer (1)}

Skillful and wise

Athlete (2), Muscleman

(1), Official athlete (1)

“...is parallel with muscleman, because $\mathrm{s} /$ he is strong, stinks of sweat, does every movements." (K34, $5^{\text {th }}$ grade).

“...is like an official athlete, because physical education teachers are good at every sport branches." (K47, $6^{\text {th }}$ grade).

3 "...is like a superman, because s/he is strong and does every movement." (K21, $5^{\text {th }}$ grade)

“...is like a Hercules, because $\mathrm{s} /$ he is very strong and teaches us everything." (K5, $5^{\text {th }}$ grade)

2

“...is like a worker, because s/he always works and doesn't get so tired." $\left(\mathrm{K} 39,6^{\text {th }}\right.$ grade)

“...is like a bee, because works non-stop.”(K10, $5^{\text {th }}$ grade)

2

Straw man (1),

Water (1)

2

Dream (1), Complicated knot (1) "...is like water, because $\mathrm{s} /$ he wets the board and make the physical education not entertaining."'(K38, $6^{\text {th }}$ grade).

"... is like a straw man, because s/he has no influence on course, leaves us free." (K35, $6^{\text {th }}$ grade)".

“...is like a complicated knot, because at start he was angry at us, couldn't understand why he was angry at us, still don't know." (K40, $7^{\text {th }}$ grade).

“...is like a dream, because I can't even dream of him/her.” (K2, $6^{\text {th }}$ grade)

In Table 2, certain categories containing metaphors of students towards physical education teacher were included. By creating these categories, generally the studies of metaphors towards how the teachers are perceived (Saban, Kocbeker, \& Saban, 2006; Cerit, 2008; Soysal \& Afacan, 2012; Altun \& Camadan, 2013; Özbas \& Aktekin, 2013) were benefited.

As it is seen in Table 2, gifted students produced 42 metaphors related to physical education teacher. By considering their resources, these metaphors were handled under 11 cognitive meaningful categories. These categories are physical education teacher as an industrious human $(\mathrm{f}=2)$, a nervous human $(\mathrm{f}=5)$, an entertaining human $(\mathrm{f}=5)$, mentor and leader $(\mathrm{f}=8)$, provider to development $(\mathrm{f}=5)$, provider of control and discipline $(\mathrm{f}=5)$, possessor of love and compassion ( $\mathrm{f}=7$ ), possessor of strength and power $(\mathrm{f}=3)$, an incompetent and ineffective human ( $\mathrm{f}=2$ ), skillful and wise ( $\mathrm{f}=4)$, a problem needed to be solved.

It was appeared that the category that has the highest frequency for gifted students' perceptions towards physical education teacher is "mentor and leader". Metaphors belonging to this category have the concepts of guiding and leading a human. Considering the subject and resource of metaphors, coach and referee as a person shaping a game, guide and psychologist as a leading a person, and also pilot metaphor of $\mathrm{K} 3$ were handled under this category. "...is like a pilot, because she/he enables us to achieve the aim". These expressions indicate that physical education teachers are perceived by students as a guide and characterized as a person leading them and guiding their skills. Also physical education teachers were with concepts such as a guardian angel, flower and friend representing good intention, beauties and good shares. The category containing these metaphors and having the second highest frequency is "possessor of love and compassion". Physical education teachers representing help, love, sharing, beauties and presenting love and compassion to students were on the other hand considered by some students as people having complicated qualifications and who are not understood. By considering the contents of dream and complicated knot metaphors containing these statements, it was stated as "a problem needed to be solved". In this category, one of the categories having the lowest frequency, the statement of "...is like a complicated knot, because at start he was angry at us, couldn't understand why he was angry at us, still don't know." (K40, $7^{\text {th }}$ grade) can be interpreted as behaviors of teacher can't be understood by 
students. This statement is supported by the participant's view of “...is like a dream, because I can't even dream of him/her. K2, $6^{\text {th }}$ grade". Besides, in the category of "an incompetent and ineffective human" having the lowest frequency and is towards the incompetence of teacher, teacher were likened to a concept of "straw man" having no effect but scaring. $\mathrm{K} 35,6^{\text {th }}$ grade participant stated that physical education teacher is like a straw man and has no effect on course and leaves the students free. When considered that fulfilling the students' necessities has an influence on loving the course, it can be inferred that it isn't fulfilled sufficiently from the opinion of K35 and K38. K38 liken the physical education course to water, and the damage of use of water unconsciously and negative effect of teacher's performance which is not adopted by students on lecturing the physical education course were likened to each other. "...is like water, because she/he wets the board and make the physical education not entertaining" (K38, $6^{\text {th }}$ grade). This statement can be interpreted as physical education teachers have deficiency in applying the course in the way of fulfilling the expectations of student. It is shown cognitive constructs related to physical education teacher of gifted students in Figure 2.

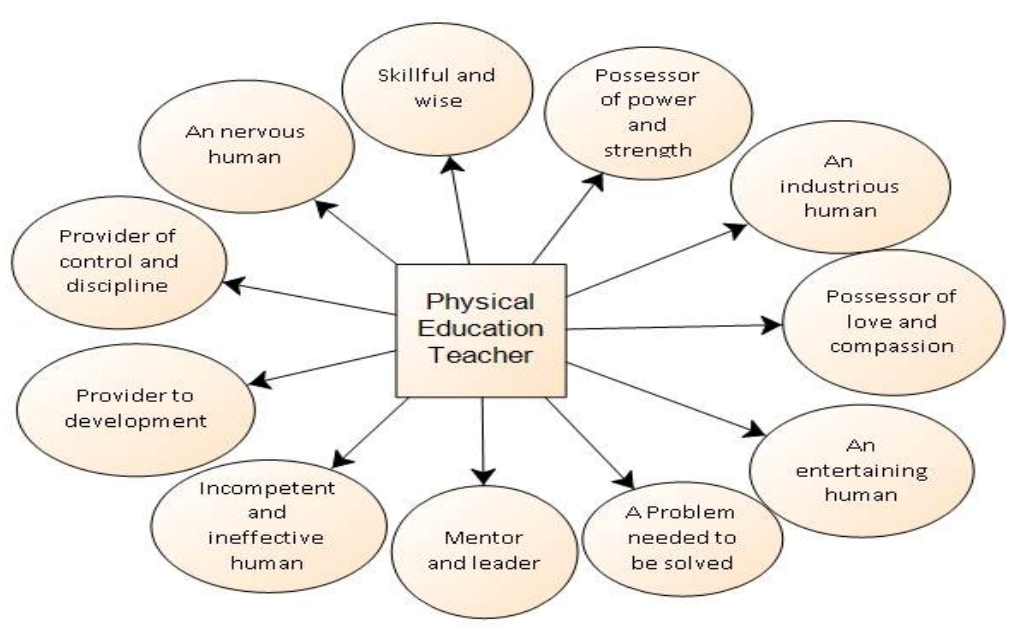

Figure 2. Cognitive constructs related to physical education teacher of gifted students

\section{Discussion and Conclusion}

In research, gifted students' cognitive structures towards physical education course were handled under 7 categories. These are the categories of "nice and entertaining course", "strict discipline tool", "educative and instructive", "life resource", "freedom tool", "competition area", "natural even". It was determined that the most dominant category is "nice and entertaining course". In this category, most repeated metaphor is sportive activities. In the study of Taskın, Tekin and Camlıca (2005) conducted to determine the expectations of students in secondary schools from physical education course, the answer for the question of "what does the concept of physical education stand for" contains generally the expression of sportive activities. This finding shares similarity with the studies of Erkmen, Tekin and Tasğın (2006) conducted to determine the opinions and attitudes of students about physical education course. In study, according to level of grade, the question of "what does the physical education words remind to you" was asked and in obtained results; it was seen that while $6^{\text {th }}$ grade students answer with sportive activities, $7^{\text {th }}$ and $8^{\text {th }}$ grade students answer with resting and relieving. It can be concluded that the higher the level of class is, the more the students feel saved from the increasing burden through physical education course. However; in present study, in contrary to this situation, it was appeared that when the level of class gets increase, students have negative emotions and thoughts towards physical education course. It was seen that with metaphors belonging to category of "strict discipline tool" including metaphors towards physical education course, students express the physical education course with negative emotions such as military service, jail, and nightmare.

Entertaining activity metaphors under the category of "nice and entertaining" towards physical education course were included. This finding shares similarity with the findings of research done by Tannehil and Zakrajsek (1983). Since they are entertaining, findings obtained in research indicated that students loved physical education course. When considered that students can be interested more in activities they love, reflecting themselves as a part of physical education course can support this opinion. Similarly, in the study of Pehlivan and Öksüzoğlu 
(2006) conducted to examine the expectations of primary $2^{\text {th }}$ grade students from physical education course, findings that contain the students requests of playing entertaining games and doing sportive activities in physical education course were reached. In the study of Smoll, Schurtz and Keeney (1976) carried out to handle the relationship between students' physical activity competence, participation and attitudes; it was figured out that there is a strong relationship between levels of attitudes and participation to activities of $5^{\text {th }}, 6^{\text {th }}$ and $7^{\text {th }}$ grade female and male students. The fact that research group in present research shares similarity with the sample in the study of Smoll, Schurtz and Keeney in terms of level of class is considered as healthy in terms of comparison. In both studies, it was appeared that students participate fondly in physical education course and have a positive perspective.

The category that has the second highest frequency towards physical education course is "physical education as a freedom tool". In this category; metaphors such as break, game and bed, holiday, no teacher in class, relief were included. It can be said that students of physical education course characterize these metaphors as a course in which restrictions are removed, they can act freely, and they reach the expectations by getting rid of intense course burden. The study of Aras (2013), conducted to examine the opinions and attitudes of students towards physical education course, supports these findings. In study, students expressed the physical education course as an activity that relieves the individual.

Gender is an important variable in studies. It was appeared that students characterizing the physical education course as a "competition area", identify this course with the metaphors of match, game and sport, an excited human; and it was determined that the whole metaphors belonging to this category were created by male students. As a competition area, football competition was included. It can be said that the fact that football as a popular sport branch is loved and adopted by society has a positive influence on the perspective of students for this branch. In the attitude studies on physical education course, it was appeared that male students have higher attitude points than female students (Sisko \& Demirhan, 2002; Koca \& Demirhan, 2004; Kangalgil, Hünük, \& Demirhan, 2006; Ekici, Bayrakdar, \& Hacıcaferoğlu, 2011).

Physical education course as "educative and instructive", objects such as wood, vase and paste were included. Since all of these are objects that can be shaped, it can be said that students expressed the physical education course with these objects as a course that develops and shapes physically them. In the study of Demirhan, Coskun and Altay (2002) conducted to examine the opinions of students towards physical education teachers, it was concluded that ideal physical education teacher should have the characteristics such as understating the students in every aspect and being qualified in professional knowledge and skills. It can be said that students can reach the developments in terms of social, physical and emotional through the teacher having the sufficient knowledge and skills in terms of professional.

Students characterized the physical education teachers as a mentor and leader. Not an uncommon metaphor, teachers are often considered guides (Patchen \& Crawford, 2011). In this category having the highest frequency, the assignment assigned to physical education teacher is a guide role that leads and flashes at the students. This guidance involves teaching the game and skills with information presented to students in classes. Metaphors such as trainer, pilot, psychologist, guide, referee can be expressed respectively as athlete, airplane, objects directing humans and competitions, and living creatures leading humans. The study of Hamilton (2016), study more than half of the metaphorical images and responses contained and communicated ideas of guides and guiding. According to Morkuiene and Juceviciene (2010), teacher is not only a person that transfers knowledge to student, but she/he is also a manager and inspector of knowledge of student (cited from: Cepelioniene \& Ivaskiene, 2014). It can be said that this information provides basis to metaphors of students in present study towards physical education course.

It was appeared that some students expressed the physical education teachers with negative objects and concepts. These are metaphors such as a scary monster, a bundle of nerves, hard rock, nightmare and murderer. These findings share similarity with the study of Avsar and Sağlam (2008) conducted on primary school students to determine the characteristics of physical education teacher. It was appeared that students give expressions containing a profile of physical education teacher who is not angry at students when they couldn't do and doesn't scream at students. No matter which branch of profession of teacher it is, when approaching a student with negative attitudes and manners, negative attitudes developed for teacher can be generalized to class. Some researches (Figlev, 1985; Carlson, 1995) states that attitudes and behaviors of teachers are important factors for students to develop positive or negative attitudes towards courses. When the thoughts of students towards are negative, reluctance, anxiety and insecurity in terms of participating in courses can reveal. It can be said that the disciplinary behaviors of teachers cause students to produce metaphors such as commander, security staff and 
guardian. Another category having negativity towards physical education teacher is "an incompetent and ineffective human". In this category, metaphors such as straw man and water were produced. This can be incurred from a common opinion in society, which is "Physical education teachers don't lecture sufficiently and they only give a ball and leave them free". Because duty of straw man is to protect the garden without doing anything. Participant stated the opinion of the fact that physical education teacher doesn't implement adequate course with this expression: "Physical education teacher is like a straw man, because she/he has no influence on course, leaves us free" ( $\mathrm{K} 35,6^{\text {th }}$ grade). It can be concluded from this that students have expectations from physical education course and these expectations aren't fulfilled sufficiently by physical education teachers. Another category is categorized the physical education teacher as "a problem needed to be solved". In this category, a complicated knot or dream metaphors are included. "Physical education teacher is like a complicated knot; because at start he was angry at us, couldn't understand why he was angry at us, still don't know" (K40, $7^{\text {th }}$ grade). Students stated that they didn't understand the behaviors of physical education teachers and they see this as a problem needed to be solved. Physical, social and spiritual characteristics are important in terms of education of students, being a model for them and leading them (Tamer \& Pulur, 2001). The behavior and personality of teacher have an influence on behaviors of students in class and their personality development (Coban \& Turan, 2006). And so, it can be said that teachers with different personality characteristics can create different results on the perspective of students. Rice (2008) concluded that $73 \%$ of students participating in physical education course define the physical education teacher as a model. The factors causing students to think so are the way of attitudes and behaviors of teacher towards students. This finding shares similarity with metaphors included in the present study's categories of possessor of love and compassion, and friend towards physical education teacher. It can be said that supposing that categories of a guardian angel, flower, a sincere friend, friend, pre-school teacher are objects or emotions containing good emotions; the teacher's way of lecturing, attitudes and behaviors towards students have an important influence on students to adopt the course. For instance, expectations of students can be an important criterion. Supposing that regularly lecturing fulfills the students' necessity of movement, physical education teacher can be considered as a good model as expectations of students are fulfilled. The fact that student $\left(\mathrm{K} 17,5^{\text {th }}\right.$ grade) characterizes the teacher as an angel because the teacher lectures regularly can be indicated as a good example for this.

Teacher, conductor of course, has a great responsibility for students' participating in course and enjoying the course. It can be said that teacher plays a key role on gaining students a good perspective. The way of perspective of teacher can influence the way of perspective physical education course. In the study of Ryan, Fleming and Maina (2003) conducted to examine the attitudes of secondary school students towards physical education course and physical education teacher, it was deduced that $13 \%$ of students don't like course because they don't like the teacher. Similar finding was found in the study of Luke and Sinclair (1991) carried out to examine the adolescents' attitudes towards physical education course; students have negative attitudes for physical education teacher with strict characteristics and this influences the perceptions for physical education course. So it is concluded that no matter which education level it is, the attitudes of students can be generalized to course.

It can be said that students have generally a positive perspective towards physical education course. It was appeared that since they are awake to contribution of course on their developments, their perceptions for course are positive. For instance, it can be deduced that students consider the course, characterized as a freedom and socializing tool, as an educative and instructive course in terms of acquiring skills and knowledge. The result that students are awake to what kind of importance the course has on their life can be associated with characterizing the course as a life resource.

Their perspectives for physical education teacher were handled under different categories. It was appeared that even though generally positive perspectives for teacher were obtained, students used the metaphors containing negative opinions. The analogy they drew for objects or concepts reveals that there are problems relations between some students with teachers. However, students and teachers should be in compliance so that education can achieve its goals.

As a result, it was concluded in present study that gifted students have generally a positive perspective for physical education course. Even though some students have negative perspective for physical education teachers, majority of students have positive perspective for teachers. As a result, these suggestions can be presented: Relationships between students' perceptions towards physical education course and teachers can be revealed. Draws that students can express the physical education course and teacher in their dreams can be included. Personal interviews can be had to handle deeply the reasons for negative metaphors towards physical education 
teachers. By conducting this study on different education levels and students with different IQ levels, difference between them can be figured out.

\section{References}

Akturan, U., \& Esen, A. (2013). Nitel arastırma yöntemleri (T. Bas, \& Akturan, Eds.). Ankara: Seckin Yayınları.

Altun, T., \& Camadan, F. (2013). Rehber öğretmenlerin rehber öğretmen (psikolojik danısman) kavramına iliskin algılarının metafor analizi yoluyla incelenmesi. Kastamonu Ĕ̆itim Dergisi, 21(3), 883-918.

Amstrong, S. L. (2008). Using metaphor analysis to uncover learners' conceptualizations of academic literacy in postsecondary developmental contexts. The International Journal of Learning, 15(9), 211-218. https://doi.org/10.18848/1447-9494/CGP/v15i09/45948

Aras, G. (2013). Illköğretim kurumlar ikinci kademede öğrenim gören ögrrenci ve görev yapan beden eğitimi ögretmenlerinin beden eğitimi dersine yönelik görüs ve tutumlarının incelenmesi (Kars ili örneği). Yüksek Lisans Tezi, Gazi Üniversitesi, Eğitim Bilimleri Enstitüsü, Ankara.

Arslan, M. M., \& Bayrakcı, M. (2006). Metaforik düsünme ve öğrenme yaklasımının eğitim-öğretim acısından incelenmesi. Milli Ĕgitim, 35(171), 100-108.

Avsar, Z., \& Sağlam, M. (2008). Beden eğitimi öğretmeni nasıl olmalıdır? İlköğretim öğrencilerinin görüsleri. İlköğretim Online, 7(3), 738-747.

Aydın, F. (2010). Ortaöğretim öğrencilerinin coğrafya kavramına iliskin sahip oldukları metaforlar. Kuram ve Uygulamada Ĕ̈itim Bilimleri, 10(3), 1293-1322.

Aydın, F., \& Ünaldı, Ü. E. (2010). Coğrafya öğretmen adaylarının "coğrafya" kavramına iliskin algılarının metaforlar yardımıyla analizi. Uluslararası Online Eğitim Bilimleri Dergisi, 2(29), 600-622.

Balc1, A. (1999). Metaphorical images of school perception of students, teachers and Parents from four selected schools in Ankara. A dissertation Submitted in Partial Fulfillment of the Requirements for the Degree of Doctor of Education Science, METU, Ankara.

Bauer, M. W. (2003). Classical content analysis: A review. In M. W. Bauer, \& G. Gaskell (Eds.), Qualitative researching with text, image and sound (pp. 131-151). London: Sage Publihing.

Billot, J., \& King, V. (2015). Understanding academic identity through metaphor. Teaching in Higher Education, 20(8), 833-844. https://doi.org/10.1080/13562517.2015.1087999

Büyüköztürk, S., Cakmak, E., Akgün, Ö., Karadeniz, S., \& Demirel, F. (2009). Bilimsel arastırma yöntemleri (3.Baskı). Ankara: Pegem Yayınevi.

Canakay, E. U. (2006). Müzik teorisi dersine iliskin tutum ölceği gelistirme. Ulusal Müzik Eğitimi Sempozyumu Bildirisi.

Cansever, B. A., \& Aslan, N. (2016). "Teacher" from the Children's Perspective: A Study by Metaphors. Journal of Education and Learning, 5(4), 21. https://doi.org/10.5539/jel.v5n4p21

Carlson, T. B. (1995). We hate gym: Student alienation from physical education. Journal of Teaching in Physical Education, 14, 467-477. https://doi.org/10.1123/jtpe.14.4.467

Casey, E. S. (2009). Remembering: A phenomenological study. Indiana University Press.

Cepelioniene, J., \& Ivaskiene, V. (2014). The shift of students attitudes towards the teacher of physical education. Education, Physical Training, Sport, 3(94), 10-15.

Cerit, Y. (2008). Öğretmen kavramı ile ilgili metaforlara iliskin öğrenci, öğretmen ve yöneticilerin görüsleri. Türk Ĕ̈itim Bilimleri Dergisi, 6(4), 693-712.

Coban, B., \& Turan, M. (2006). Öğrenci görüslerine göre ideal beden eğitimi öğretmeninin nitelikleri: Olcek gelistirme calısması. Firat Üniversitesi Sosyal Bilimler Dergisi, 16(1), 149-161.

Demirhan, G. (2006). Spor eğitiminin temelleri. Ankara: Bağırgan Yayınları.

Demirhan, G., Coskun, H., \& Altay, F. (2002). Beden eğitimi öğretmenlerinin niteliklerine iliskin görüsleri. Eğitim ve Bilim, 27(123), 35-41.

Demirtas, H., \& Coban, D. (2014). Üniversite öğrencilerinin öğretim elemanlarına iliskin metaforları. Kastamonu Ĕ̈itim Dergisi, 22(3), 1279-1300. 
Ekici, S., Bayrakdar, A., \& Hacıcaferoğlu, B. (2011). Lise öğrencilerinin beden eğitimi dersi tutumlarının değerlendirilmesi. Uluslar arası Ínsan Bilimleri Dergisi, 8(1), 829-839.

Ekiz, D. (2009). Bilimsel arastırma yöntemleri. Ankara: Anı Yayıncılık.

Emerson, L., \& Mansvelt, J. (2014). If they're the customer, I'm the meat in the sandwich: An exploration of tertiary teachers' metaphorical constructions of teaching. Higher Education Research \& Development, 33(3), 469-482. https://doi.org/10.1080/07294360.2013.841653

Eraslan Capan, B. (2010). Öğretmen adaylarının üstün yetenekli öğrencilere iliskin metaforik algıları. Uluslararası Sosyal Arastırmalar Dergisi, 3(12), 140-154.

Erkmen, G., Tekin, M., \& Tasğın, Ö. (2006). Özel ilköğretim okullarında öğrenim gören öğrencilerin cesitli değiskenlere göre beden ĕgitimi dersi hakkindaki tutum ve görüsleri. Uluslar arası Spor Bilimleri Kongresinde Sözel Bildiri Olarak Sunuldu, Muğla.

Figley, E. F. (1985). Determinations of attitudes toward physical education. Journal of Teaching in Physical Education, 4, 229-240. https://doi.org/10.1123/jtpe.4.4.229

Forceville, C. (2002). The identification of target and source in pictorial metaphor. Journal of Pragmatics, 34, 1-14. https://doi.org/10.1016/S0378-2166(01)00007-8

Fraenkel, J. R., \& Wallen, N. (2000). How to design and evaluate research in education (4th ed.). NY: McGraw-Hill.

Gahofrani, M., \& Golsanamlou, M. (2012).S tudents' perception of physical education courses and its relationship with their participation in sport activities. Sport Scientific \& Practical Aspects, 9(1), 21-31.

Gömleksiz, M. N., Kan, A. Ü., \& Öner, Ü. (2012). İlköğretim öğrencilerinin sosyal bilgiler dersine iliskin metaforik algıları. Erzincan Üniversitesi Ë̆itim Fakültesi Dergisi, 14(2), 419-436.

Güven, B. (2007). Öğretim ilke ve yöntemleri. Ankara: Pegem A Yayıncılık.

Hamilton, E. R. (2016). Picture This: Multimodal representations of prospective teachers' metaphors about teachers and teaching. Teaching and Teacher Education, 55, 33-44. https://doi.org/10.1016/j.tate.2015.12.007

Harrison, M. J., \& Blakemore, C. L. (1992). Instructional strategres for seconday school physical education. Dubuque: Wm.C. Brown Pub.

Kangalgil, M., Hünük, D., \& Demirhan, G. (2006). İlköğretim, lise ve üniversite öğrencilerinin beden eğitimi ve spora iliskin tutumlarının karsılastırılması. Hacettepe Spor Bilimleri Dergisi, 17(2), 48-57.

Koca, C., \& Demirhan, G. (2004). An examination of high school students' attitudes toward physical education with regard to sex and sport participation. Perceptual and Motor Skills, 98, 754-758. https://doi.org/10.2466/pms.98.3.754-758

Lakoff, G., \& Johnson, M. (1980). The metaphorical structure of the human conceptual system. Cognitive Science, 4, 195-208. https://doi.org/10.1207/s15516709 $\operatorname{cog} 0402 \_4$

Lakoff, G., \& Johnson, M. (2010). Metaforlar: Hayat, anlam ve dil (Cev: G.Y. Demir). Paradigma, İstanbul.

Low, G., Deignan, A., Cameron, L., \& Todd, Z. (Eds.). (2010). Researching and applying metaphor in the real world (Vol. 26). John Benjamins Publishing. https://doi.org/10.1075/hcp.26

Luke, M. D., \& Sinclair, G. D. (1991). Gender differences in adolescents' attitudes toward physical education. Journal of Teaching in Physical Education, 11,31-46. https://doi.org/10.1123/jtpe.11.1.31

Massengill Shaw, D., \& Mahlios, M. (2008). Pre-service teachers' metaphors of teaching and literacy. Reading Psychology, 29(1), 31-60. https://doi.org/10.1080/02702710701568397

Mertol, H., Doğdu, M., \& Yılar, B. (2013). Üstün zekâlı ve yetenekli öğrencilerin sosyal bilgiler dersine iliskin metaforik algıları. Üstün Yetenekliler Ĕgitimi ve Arastırmaları Dergisi (UYAD), l(3).

Miles, M. B., \& Huberman, A. M. (1994). Qualitative date analysis (2nd ed.). United Kingdom: Sage pub.

Ocak, G., \& Beskardes Günay, S. (2009). Üstün ve özel yetenekli öğrencilerin yabancı dil (ingilizce) öğretiminde metafor sisteminin uygulanması. Milli Ĕ̈itim, 182.

Özbas, B. C., \& Aktekin, S. (2013). Tarih öğretmen adaylarının tarih öğretmenliğine iliskin inanclarının metafor analizi yoluyla incelenmesi. Eğitimde Kuram ve Uygulama, 9(3), 211-228. 
Özsoy, Y. (2014). Bilim ve sanat merkezi öğrenci, öğretmen ve velilerinin üstün yetenekli öğrenci kavramına iliskin metaforları. Üstün Yetenekliler Eğitimi Arastırmaları Dergisi, 2(19), 74-87.

Patchen, T., \& Crawford, T. (2011). From gardeners to tour guides: The epistemological struggle revealed in teacher-generated metaphors of teaching. Journal of Teacher Education, 62(3), 286-298. https://doi.org/10.1177/0022487110396716

Patton, M. Q. (2001). Qualitative evaluation and research methods. Newsbury: Sage Publication.

Pehlivan, Z., \& Öksüzoğlu, P. (2006). İlköğretim ikinci kademe öğrencilerinin beden eğitimi dersinden beklentileri. Uluslar arası Spor Bilimleri Kongresi, Muğla.

Rice, P. L. (2006). Attitudes of high school students towards physical education activities, teachers and personal health. Physical Educator, 45(2), 94-99.

Ryan, S., Fleming, D., \& Maina, M. (2003). Attitudes of middle school student toward their physical education teachers and class. Physical Educator, 60(2), 28-42.

Saban, A. (2008). İlköğretim I. Kademe öğretmen ve öğrencilerinin bilgi kavramına iliskin sahip oldukları zihinsel imgeler. Türk Ĕ̈itim Bilimleri Dergisi, 7(2), 281-326.

Saban, A., Kocbeker, B. N., \& Saban, A. (2006). Öğretmen adaylarının öğretmen kavramına iliskin algılarının metaphor analizi yoluyla incelenmesi. Kuram ve Uygulamada Eğitim Bilimleri, 6(2), 461-522.

Schmitt, R. (2005). Systematic metaphor analysis as a method of qualitative research. The Qualitative Report, 10(2), 358-394.

Silverman, S., \& Scrabis, K. A. (2004). A Review of research on instructional theory in physical education 2002 2003. International Journal of Physical Education, 41(1), 4-12.

Smoll, F. L., Suchutz, R. W., \& Keeney, J. K. (1976). Relationships among children's attitudes, involvement, and proficiency in physical activity. The Research Quarterly, 47, 797-803.

Soysal, D., \& Afacan, Ö. (2012). İlköğretim öğrencilerinin "fen ve teknoloji dersi" ve "fen ve teknoloji öğretmeni kavramlarına yönelik metafor durumları. Mustafa Kemal Üniversitesi Sosyal Bilimler Enstitüsü Dergisi, 9(19), 287-306.

Sahin, B. (2013). Öğretmen adaylarının "matematik öğretmeni”, "matematik" ve "matematik dersi” kavramlarına iliskin sahip oldukları metaforik algıları. Mersin Üniversitesi Eğitim Fakültesi Dergisi, 9(1), 313-321.

Sisko, M., \& Demirhan, G. (2002). İlköğretim okulları ve liselerde öğrenim gören kız ve erkek öğrencilerin beden eğitimi ve spor dersine iliskin tutumları. Hacettepe Üniversitesi Eğitim Fakültesi Dergisi, 23, 205-210.

Tamer, K., \& Pulur, A. (2001). Beden eğitimi ve sporda öğretim yöntemleri. Ankara: Kozan Ofset.

Tannehil, D., \& Zakrajsek, D. (1993). Student attitudes towards physical education: A multicultural Study. Journal of Teaching in Physical Education, 13, 78-84. https://doi.org/10.1123/jtpe.13.1.78

Taskın, O., Tekin, M., \& Camlıca, C. (2005). Ortaöğretim kurumlarında öğrenim gören öğrencilerin cesitli değiskenlere gore beden eğitimi dersinden beklentileri. Eğitim Bilim Toplum Dergisi, 4(13), 80-95.

Thomas, L., \& Beauchamp, C. (2011). Understanding new teachers' professional identities through metaphor. Teaching and Teacher Education, 27(4), 762-769. https://doi.org/10.1016/j.tate.2010.12.007

Tortop, H. S. (2013). Öğretmen adaylarının üniversite hocası hakkındaki metaforları ve bir değerlendirme arac1 olarak metafor. Yüksekögrretim ve Bilim Dergisi, 3(2), 153-160.

Ungar, O. A. (2016). Understanding teachers' attitude toward educational reforms through metaphors. International Journal of Educational Research, 77, 117-127. https://doi.org/10.1016/j.ijer.2016.03.008

Wan, W. (2014). Constructing and developing ESL students' beliefs about writing through metaphor: In exploratory study. Journal of Second Language Writing, 23, 53-73. https://doi.org/10.1016/j.jslw.2014.01.002

Yalcın, M., \& Erginer, A. (2012). İlköğretim okullarında okul müdürüne iliskin metaforik algıları. Öğretmen Ĕ̈itimi ve Ĕ̈itimcileri Dergisi, 1(2), 229-256.

Yıldırım, A., \& Simsek, H. (2011). Sosyal bilimlerde nitel arastırma yöntemleri (8. Baskı). Ankara: Seckin Yayınları. 
Yılmaz, A., \& Güven, Ö. (2015). Üstün yetenekli öğrencilerin beden eğitimi dersi ve beden eğitimi öğretmeni kavramlarına yönelik algılarının cizme yazma tekniği ile incelenmesi. Journal of Qualitative Research in Education, 3(3), 55-77. https://doi.org/10.14689/issn.2148-2624.1.3c3s3m

Yin, R. K. (2003). Case Study Research (3rd ed.). California: Sage Publishing.

Yob, I. M. (2003). Thinking constructively with metaphors. Studies in Philosophy and Education, 22(2), 127-138. https://doi.org/10.1023/A:1022289113443

\section{Note}

Note 1. Part of this study was presented as a verbal announcement in the 16th International scientific conference "perspectives in physical education and sport". 20-22 May 2016, Constanta, Romania.

\section{Copyrights}

Copyright for this article is retained by the author(s), with first publication rights granted to the journal.

This is an open-access article distributed under the terms and conditions of the Creative Commons Attribution license (http://creativecommons.org/licenses/by/4.0/). 